\title{
Uric Acid as a Predictor of Adverse Maternal and Perinatal Outcomes in Women Hospitalized With Preeclampsia
}

\author{
Joel R. Livingston, MSc ${ }^{1,2}$, Beth Payne, BSc ${ }^{1,2}$, Mark Brown, MB, BS, MD, ${ }^{3}$ James M. Roberts, MD, ${ }^{4}$ \\ Anne-Marie Côté, MD, MHSc ${ }^{5}$, Laura A. Magee, MD, FRCPC, MSc, ${ }^{1,2}$ \\ Peter von Dadelszen, MBChB, DPhil, FRCSC ${ }^{1,2,6}$; for the PIERS Study Group
}

${ }^{1}$ Department of Obstetrics and Gynaecology, University of British Columbia, Vancouver BC

${ }^{2}$ The CFRI Reproduction and Healthy Pregnancy Cluster, University of British Columbia, Vancouver BC

${ }^{3}$ Department of Renal Medicine, St. George Hospital Kogarah and University of NSW, Sydney Australia

${ }^{4}$ Department of Obstetrics, Gynaecology and Reproductive Sciences, Magee-Womens Research Institute and University of Pittsburgh, Pittsburgh PA

${ }^{5}$ Department of Medicine, Université de Sherbrooke, Sherbrooke QC

${ }^{6}$ School of Population and Public Health, University of British Columbia, Vancouver BC

\section{Abstract}

Objective: Elevated serum uric acid is commonly observed in women with preeclampsia, but its utility in predicting adverse outcomes has recently been disputed. Our goal was to analyze data from a large cohort of women with preeclampsia to determine the utility of serum uric acid in predicting adverse maternal and perinatal outcomes.

Methods: Data were obtained from an ongoing international prospective study of women admitted to hospital with preeclampsia (Pre-eclampsia Integrated Estimate of RiSk). Univariate logistic regression was used to determine the relationship between serum uric acid concentration (both absolute and gestational-age corrected [ $Z$ score]) and adverse outcomes (maternal and perinatal). Analyses were conducted to compare cohorts of women with preeclampsia as defined by hypertension and proteinuria versus hypertension and hyperuricemia.

Results: Uric acid $Z$ score was associated with adverse perinatal outcome (OR $1.5 ; 95 \% \mathrm{Cl} 1.4$ to 1.7 ) and had a point estimate $>0.7$ (area under the curve receiver operating characteristic $0.72 ; 95 \% \mathrm{Cl} 0.69$ to 0.74 ). Serum uric acid concentration also showed a significant association with adverse maternal outcomes, but the point estimate was $<0.7$. No significant differences were observed between groups in which preeclampsia was defined

Key Words: Preeclampsia, pregnancy outcome, risk assessment, uric acid

Competing Interests: None declared.

Received on April 23, 2014

Accepted on July 8, 2014 by hypertension and proteinuria and by hypertension and hyperuricemia.

Conclusion: In women admitted to hospital with preeclampsia, the serum uric acid concentration, corrected for gestational age via a $Z$ score, is clinically useful in predicting adverse perinatal outcomes but not maternal outcomes.

\section{Résumé}

Objectif : Bien qu'un taux sérique élevé d'acide urique soit couramment constaté chez les femmes qui présentent une prééclampsie, son utilité pour ce qui est de la prévision des issues indésirables a récemment été remise en question. Nous avions pour objectif d'analyser les données issues d'une importante cohorte de femmes présentant une prééclampsie, afin de déterminer l'utilité du taux sérique d'acide urique pour ce qui est de la prévision des issues indésirables maternelles et périnatales.

Méthodes : Les données ont été tirées d'une étude prospective internationale toujours en cours qui porte sur des femmes hospitalisées présentant une prééclampsie (Pre-eclampsia Integrated Estimate of RiSk). Une régression logistique univariée a été utilisée pour déterminer la relation entre la concentration sérique en acide urique (tant absolue que corrigée en fonction de l'âge gestationnel [score Z]) et les issues indésirables (maternelles et périnatales). Des analyses ont été menées pour comparer des cohortes de femmes présentant une prééclampsie définie par l'hypertension et la protéinurie à des cohortes de femmes présentant une prééclampsie définie par l'hypertension et l'hyperuricémie.

Résultats : Le score $Z$ quant à l'acide urique était associé à des issues périnatales indésirables (RC, 1,5; IC à $95 \%, 1,4-1,7)$ et comptait une estimation ponctuelle $>0,7$ (surface sous la courbe 
de la fonction d'efficacité de l'observateur, 0,72; IC à $95 \%$, $0,69-0,74)$. Une association significative a également été constatée entre la concentration sérique en acide urique et des issues indésirables maternelles; toutefois, l'estimation ponctuelle était $<0,7$. Aucune différence significative n'a été constatée entre les groupes « prééclampsie définie par l'hypertension et la protéinurie » et « prééclampsie définie par l'hypertension et l'hyperuricémie ».

Conclusion : Bien que la concentration sérique en acide urique (corrigée en fonction de l'âge gestationnel par l'intermédiaire d'un score Z) soit utile sur le plan clinique pour ce qui est de la prévision des issues indésirables périnatales chez les femmes hospitalisées présentant une prééclampsie, elle ne compte pas une utilité semblable en ce qui concerne les issues indésirables maternelles.

J Obstet Gynaecol Can 2014;36(10):870-877

\section{INTRODUCTION}

$\mathrm{D}$ espite advances in care, preeclampsia remains a leading cause of maternal and perinatal morbidity and mortality worldwide. ${ }^{1}$ Preeclampsia affects multiple organ systems and can lead to severe renal, hepatic, neurological, and cardiopulmonary complications. Often the fetus is affected, and adverse perinatal outcomes include preterm birth, intrauterine growth restriction, and death. Ultimately, delivery is the only definitive treatment for preeclampsia; however, many cases can be managed expectantly with increased maternal and fetal monitoring, maternal blood pressure control, and maternal seizure prophylaxis. The challenge in caring for women with preeclampsia is to identify those who are at increased risk for complications so that appropriate and timely delivery can be offered. The Pre-eclampsia Integrated Estimate of RiSk research program was conceived to address this critical need in preeclampsia management. Using a combination of maternal demographics, signs, symptoms, and laboratory findings, the fullPIERS model can successfully identify women at risk for preeclampsia complications so that they can access appropriate care ${ }^{2}$; the miniPIERS model uses solely demographics, symptoms, and signs. ${ }^{3}$

A frequently reported laboratory finding in women with preeclampsia is elevated serum uric acid. Most accept that hyperuricemia in women with preeclampsia is primarily a result of a reduction in glomerular filtration rate, although others have suggested a possible role for elevated uric acid levels in the pathogenesis of preeclampsia, via endothelial dysfunction. ${ }^{4-6}$ Reports linking elevated uric acid

\section{ABBREVIATIONS}

\section{AUC area under the curve}

PIERS Pre-eclampsia Integrated Estimate of RiSk

ROC receiver operating characteristic concentrations with adverse maternal or perinatal outcomes have described mixed results. Some investigators propose that the serum uric acid concentration is useful in predicting either adverse maternal or fetal outcomes, ${ }^{7-9}$ while others suggest that an increased uric acid concentration is a poor predictor of maternal and fetal outcomes., ${ }^{3,10,11}$ Part of the challenge in assessing uric acid as a marker in women with preeclampsia is that the serum uric acid concentration is known to vary throughout normal gestation. ${ }^{12}$ To address this, Roberts et al. ${ }^{9}$ and more recently Hawkins et al. ${ }^{13}$ proposed using a gestational age-corrected $Z$ score, based on the data of Lind et al., ${ }^{12}$ and concluded that measurement of serum uric acid aids in the prediction of adverse maternal and particularly perinatal outcomes.

The goal of this study was to assess, among a large cohort of 2514 women hospitalized with preeclampsia, whether the maternal serum uric acid concentration (corrected for gestational age) will identify women at increased risk for adverse maternal or perinatal outcomes.

\section{METHODS}

Data for this study were obtained from PIERS, an ongoing international prospective study of women admitted to hospital with preeclampsia. ${ }^{2}$ The following tertiary obstetric centres were involved: in Canada, British Columbia's Women's Hospital, Vancouver, BC; Kingston General Hospital, Kingston, ON; Ottawa Hospital, Ottawa, ON; and Centre Hospitalier Universitaire de Sherbrooke, Sherbrooke, QC; in the United Kingdom, St. James's University Hospital, Leeds and Nottingham University Hospital, Nottingham; in Australia, King Edward Memorial Hospital, Subiaco, Western Australia; and in New Zealand, Christchurch Women's Hospital, Christchurch. Data were collected between September 2003 and December 2011. Until 2007, four sites required subjects to provide informed consent prior to enrolment. Thereafter, women were enrolled as part of a continuous quality improvement project at all but one site. Regardless of timing, local research ethics boards approved participation at each site before subject recruitment.

The PIERS study ${ }^{2}$ collected data on women with:

1. hypertension and proteinuria,

2. hypertension and hyperuricemia,

3. HELLP syndrome, and

4. superimposed preeclampsia.

In the current study, our primary analysis included only women with hypertension and proteinuria. Preeclampsia was defined as hypertension (systolic blood pressure $\geq 140 \mathrm{mmHg}$ and/or diastolic blood pressure $\geq 90 \mathrm{mmHg}$ 
on $\geq 2$ recordings taken $\geq 4$ hours apart, after 20 weeks' gestation) with proteinuria ( $\geq 2+$ by dipstick, $\geq 0.3 \mathrm{~g} /$ day by 24 -hour urine excretion, or $\geq 30 \mathrm{mg} / \mathrm{mmol}$ by spot urine protein:creatinine ratio).

For comparison, we also conducted a supplemental analysis of women with hypertension (as defined above), without proteinuria (as defined above), and with hyperuricemia (serum uric acid level greater than the upper limit of normal for non-pregnant individuals at each study site).

Exclusion criteria were met if women were admitted to hospital in spontaneous labour or if they had experienced any adverse outcome before fulfilling eligibility criteria and the collection of predictor variables.

Adverse outcomes were classified as either maternal or perinatal. Maternal outcomes were recorded at 48 hours, seven days, or any time, and comprised maternal death or any of the following morbidities by system: hepatic (hepatic dysfunction, hematoma, or rupture); CNS (eclampsia, Glasgow coma score $<13$, stroke, reversible ischemic neurological deficit, transient ischemic attack, posterior reversible encephalopathy, cortical blindness, or retinal detachment); renal (acute renal insufficiency, defined as serum creatinine $>150 \mathrm{mM}$ among women without pre-existing renal disease or $>200 \mathrm{mM}$ among women with pre-existing renal disease, or dialysis); respiratory (pulmonary edema, requirement $\geq 50 \% \mathrm{FiO}_{2}$ for $\geq 1$ hour, or intubation other than for Caesarean section); cardiovascular (need for positive inotrope support, infusion of a third parenteral antihypertensive, or myocardial ischemia/ infarction [symptoms; electrocardiogram changes of ST segment changes, or $\mathrm{Q}$ waves; biochemical markers of troponin or creatine kinase- $\mathrm{MB}$, coronary artery intervention, or pathological findings]); or hematologic (transfusion of any blood product). Perinatal outcomes were recorded at any time and comprised perinatal or infant mortality, admission to NICU for greater than 48 hours, or both.

Serum uric acid concentration was measured within 24 hours of enrolment, and the highest level recorded. If there was no value recorded within the 24 hours of enrolment, the highest measure recorded within two weeks before admission was carried forward (if available). Local laboratories at each site were responsible for measurement of serum uric acid, and we relied on existing quality control procedures to ensure test reproducibility. The estimated date of delivery was also recorded for all women and was used to calculate gestational age at enrolment.

All symptom and outcome data from patient charts were entered on a PIERS data collection form and then into the PIERS Microsoft Access database (Microsoft Corp., Redmond WA).

The relationship between uric acid concentrations and adverse outcomes was examined in two ways. First, both the highest uric acid level and a gestational age-corrected $Z$ score of highest uric acid level:

$$
\text { uric acid } Z \text { score }=\frac{\begin{array}{c}
\text { highest uric acid level } \\
\text { - mean uric acid level for GA }
\end{array}}{\text { SD of uric acid level for GA }}
$$

were analyzed as continuous variables in univariate logistic regression to determine the relationship with adverse maternal (at 48 hours, at 7 days, at any time) and perinatal (at any time) outcomes. The odds ratio for each was determined, a receiver operating characteristic curve was constructed, and the area under the curve calculated. According to statistical standards, ${ }^{14}$ an AUC ROC of 1.0 would define a perfect correlation, while an AUC ROC of 0.5 would define no correlation. Based on this, an AUC ROC value of 0.7 was set as the minimum threshold for a discriminative test. Second, hyperuricemia and hyperuricemia corrected for gestational age (defined as one standard deviation above the mean value for gestational age; for example, serum uric acid $>0.27 \mathrm{mmol} / \mathrm{L}$ between 32 and 35 weeks' gestation) were also examined as dichotomous variables to further assess relationships with adverse maternal and perinatal outcomes. Analyses were conducted on these dichotomous variables to determine the sensitivity and specificity of detecting adverse maternal and/or perinatal outcomes. Data from Lind et al. were used for the mean and standard deviation of serum uric acid at each gestational age period. ${ }^{12}$

Given the fundamental link between renal function and serum uric acid concentration, we conducted sensitivity analyses in which women with solely adverse renal outcomes were coded as "normal." In addition, we examined the correlation between serum creatinine and serum uric acid.

Univariate logistic regression (AUC ROC, beta coefficients) and chi-squared analyses were completed using STATA version 12.1 (Statacorp, College Station, TX). All other calculations were conducted using Microsoft Excel 2011 (Microsoft Corp., Redmond WA).

\section{RESULTS}

Data were collected on 1505 women who met the eligibility criteria for enrolment in the primary analysis of study (hypertension and proteinuria). Of these 1505 women, 1487 (99\%) had complete data, 199 (13\%) experienced an adverse maternal outcome at any point after their 


\begin{tabular}{|c|c|c|c|}
\hline & $\begin{array}{l}\text { Full cohort } \\
(n=1487)\end{array}$ & $\begin{array}{l}\text { Adverse maternal } \\
\qquad(\mathrm{n}=199)\end{array}$ & $\begin{array}{l}\text { Adverse perinatal } \\
\qquad(n=420)\end{array}$ \\
\hline Demographics & & Median (IQR) & \\
\hline Maternal age, years (at EDC) & 31 (26 to 35$)$ & 31 (27 to 35$)$ & 30 (26 to 34$)$ \\
\hline \multirow[t]{2}{*}{ Gestational age, weeks (at onset) } & 35 (33 to 38$)$ & $34(30 \text { to } 37)^{\star *}$ & 35 (32 to 38$)$ \\
\hline & & $\mathrm{n}(\%)$ & \\
\hline Gestational age $<34$ weeks (at onset) & $463(31)$ & $98(49)^{* *}$ & $142(34)$ \\
\hline Multiple pregnancy & $141(10)$ & $29(15)^{\star *}$ & $41(10)$ \\
\hline Parity $\geq 1$ & $390(26)$ & $49(25)$ & $110(26)$ \\
\hline Clinical assessments (within 48 hours of eligibility) & & Median (IQR) & \\
\hline Systolic BP, mmHg & 160 (150 to 175$)$ & $165(150 \text { to } 180)^{* *}$ & 160 (150 to 178$)$ \\
\hline Diastolic BP, mmHg & 100 (95 to 110$)$ & $103(95 \text { to } 110)^{*}$ & 100 (95 to 110$)$ \\
\hline Worst dipstick proteinuria & $2+(1+$ to $3+)$ & $3+(2+\text { to } 4+)^{* *}$ & $2+(1+$ to $3+)$ \\
\hline Lowest platelet concentration $\left(\times 10^{9} / \mathrm{L}\right)$ & 200 (144 to 247$)$ & 194 (156 to 241$)$ & 211 (167 to 257 ) \\
\hline Highest aspartate transaminase (IU/L) & 26 (20 to 37 ) & 26 (20 to 38$)$ & $28(21$ to 40$)++$ \\
\hline Lowest $\mathrm{SpO}_{2}, \%$ & 97 (96 to 97 ) & 97 (95 to 97 ) & $96(95$ to 97$)+$ \\
\hline Uric acid $Z$ score & 2.67 (1.36 to 3.75$)$ & $3.58(2.14 \text { to } 4.98)^{\star *}$ & $3.75(2.37$ to 4.85$)++$ \\
\hline Interventions & & $\mathrm{n}(\%)$ & \\
\hline Corticosteroid administered $(\mathrm{Y})$ & $409(28)$ & $58(29)$ & $236(56)++$ \\
\hline Antihypertensive medications $(\mathrm{Y})$ & $1032(69)$ & $137(69)$ & $353(84)++$ \\
\hline $\mathrm{MgSO}_{4}$ administered $(\mathrm{Y})$ & $524(35)$ & $74(37)$ & $212(50)$ \\
\hline Pregnancy outcomes & & Median (IQR) & \\
\hline Admission-to-delivery interval, days & 2 (1 to 6$)$ & $2(1$ to 5$)$ & $3(1$ to 7$)++$ \\
\hline Gestational age at delivery, weeks & 37 (34 to 39$)$ & $34(31 \text { to } 37)^{\star *}$ & 37 (34 to 38$)$ \\
\hline \multirow[t]{2}{*}{ Birth weight, $g$} & 2600 (1803 to 3241$)$ & 2560 (1868 to 3144$)$ & $1470(1100$ to 1955$)++$ \\
\hline & & $\mathrm{n}(\%)$ & \\
\hline Intrauterine fetal death $(\mathrm{Y})$ & $14(0.9)$ & $0(0)$ & $14(3.3)++$ \\
\hline Neonatal death $(Y)$ & $15(1.0)$ & $1(0.5)$ & $15(3.6)++$ \\
\hline Small for gestational age ( $<10$ th centile) & $125(8.4)$ & $19(9.5)$ & $46(11)+$ \\
\hline
\end{tabular}

IQR: interquartile range; EDC: estimated date of confinement.

Significant differences between the full cohort and adverse maternal outcome cohort are indicated by ${ }^{*} P<0.05$ and ${ }^{*} P<0.01$. Significant differences between the full cohort and adverse perinatal outcome cohort are indicated by $+P<0.05$ and $++P<0.01$. $P$ values for differences were calculated using the Mann-Whitney $U$ test for medians and the chi-squared test for frequencies.

admission (196 non-renal adverse outcomes), and 420 $(28 \%)$ experienced an adverse perinatal outcome.

Demographics for the study cohort are shown in Table 1. Women who experienced an adverse maternal or perinatal outcome had earliergestational age, elevated blood pressure, and higher levels of proteinuria. Women who experienced an adverse perinatal outcome were more likely to have had interventions (e.g., treatment with corticosteroids or antihypertensives) and elevated levels of the liver enzyme aspartate transaminase.

In univariate analysis (Table 2), uric acid $Z$ score was associated with adverse perinatal outcome (OR 1.5; 95\% CI 1.4 to 1.7$)$ and met the threshold for a discriminative test with point estimate $>0.7$ (AUC ROC $0.72 ; 95 \%$ CI 0.69 to 0.74 ). The association between uric acid $Z$ score and adverse maternal outcomes was also significant for all time-frames of adverse maternal outcome occurrence investigated but the point estimate was $<0.7$ (although the upper 95\% CI did cross 0.70 at some time points). Uric acid concentration analyzed without standardization was associated with adverse maternal and perinatal outcomes; however, both the point estimates and upper 95\% CI were $<0.70$, the minimum for a clinically useful test.

Eliminating purely adverse renal events from the analysis of adverse maternal outcomes had no effect on the analysis of either uric acid concentration or uric acid $Z$ score (Table 2). Analyzing the relationship between highest 


\begin{tabular}{|c|c|c|c|c|c|}
\hline Variable & Outcome type & Time & OR $(95 \% \mathrm{Cl})$ & $P$ & AUC ROC $(95 \% \mathrm{Cl})$ \\
\hline \multirow{4}{*}{ Uric acid concentration } & & 7 days & $\begin{array}{c}1.0048 \\
(1.0039 \text { to } 1.0066)\end{array}$ & $<0.001$ & $\begin{array}{c}0.6086 \\
(0.5617 \text { to } 0.6555)\end{array}$ \\
\hline & $\begin{array}{l}\text { Adverse maternal } \\
\text { (non-renal) }\end{array}$ & $48 \mathrm{hrs}$ & $\begin{array}{c}1.0050 \\
(1.0028 \text { to } 1.0074)\end{array}$ & $<0.001$ & $\begin{array}{c}0.6138 \\
(0.5508 \text { to } 0.6768)\end{array}$ \\
\hline & & 7 days & $\begin{array}{c}1.0045 \\
(1.0028 \text { to } 1.0064)\end{array}$ & $<0.001$ & $\begin{array}{c}0.6051 \\
(0.5580 \text { to } 0.6522)\end{array}$ \\
\hline & & Any time & $\begin{array}{c}1.0035 \\
(1.0018 \text { to } 1.0052)\end{array}$ & $<0.001$ & $\begin{array}{c}0.5784 \\
(0.5344 \text { to } 0.6225)\end{array}$ \\
\hline \multirow[t]{5}{*}{$\begin{array}{l}\text { Gestational age corrected } \\
Z \text { score of uric acid level }\end{array}$} & Adverse maternal (all) & $48 \mathrm{hrs}$ & $\begin{array}{c}1.3143 \\
(1.1928 \text { to } 1.4481)\end{array}$ & $<0.001$ & $\begin{array}{c}0.6509 \\
(0.5920 \text { to } 0.7098)\end{array}$ \\
\hline & & 7 days & $\begin{array}{c}1.3318 \\
(1.2302 \text { to } 1.4417)\end{array}$ & $<0.001$ & $\begin{array}{c}0.6603 \\
(0.6157 \text { to } 0.7049)\end{array}$ \\
\hline & & Any time & $\begin{array}{c}1.3052 \\
(1.2114 \text { to } 1.4063)\end{array}$ & $<0.001$ & $\begin{array}{c}0.6456 \\
(0.6036 \text { to } 0.6876)\end{array}$ \\
\hline & $\begin{array}{l}\text { Adverse maternal } \\
\text { (non-renal) }\end{array}$ & $48 \mathrm{hrs}$ & $\begin{array}{c}1.2865 \\
(1.1663 \text { to } 1.4191)\end{array}$ & $<0.001$ & $\begin{array}{c}0.6436 \\
(0.5842 \text { to } 0.7030)\end{array}$ \\
\hline & & 7 days & $\begin{array}{c}1.3182 \\
(1.2171 \text { to } 1.4275)\end{array}$ & $<0.001$ & $\begin{array}{c}0.6589 \\
(0.6142 \text { to } 0.7036)\end{array}$ \\
\hline
\end{tabular}

uric acid levels and serum creatinine showed a Pearson's correlation coefficient of $0.46(P<0.001)$.

For our supplemental analysis, we included data on 395 women with preeclampsia defined as the presence of hypertension and hyperuricemia alone. In this additional cohort, 27 women had an adverse maternal outcome occurring at any point during their hospital stay, and 12 of these occurred within 48 hours of admission. The results from the hypertension and hyperuricemia cohort paralleled the hypertension and proteinuria cohort (the primary analysis group). Again only the association between uric acid $Z$ score and adverse perinatal outcomes met the minimum criteria for a clinically useful test (OR 1.9; $95 \%$ CI 1.57 to 2.39; AUC ROC 0.75 ; $95 \%$ CI 0.67 to 0.82) (Table 3).

When hyperuricemia and hyperuricemia corrected for gestational age were dichotomized, correcting for gestational age enhanced sensitivity but decreased specificity for both maternal and perinatal outcomes (Table 4). This was particularly true for prediction of adverse perinatal outcome. Uric acid $Z$ score as a predictor of perinatal outcome was associated with a positive likelihood ratio of 1.27 (95\% CI 1.21 to 1.33$)$.

\section{DISCUSSION}

In this large cohort of women admitted to hospital with preeclampsia, the observed relationship between uric acid $Z$ score and adverse perinatal outcome (OR 1.5; 95\% CI 1.4 to 1.6$)$ is slightly weaker than results from previous work by Hawkins et al., ${ }^{13}$ who demonstrated an OR of 2.4 (95\% CI 1.7 to 3.4) for a composite of adverse fetal outcomes in a cohort of 1142 women with preeclampsia. However, our analysis of the association of absolute uric acid level with perinatal outcomes (OR 1.00; 95\% CI 1.00 to 1.00) shows overlap with the findings of Hawkins et al. (OR 1.4; $95 \%$ CI 1.0 to 1.9 ).

Differences in the definition of adverse perinatal outcome likely account for these variations. Hawkins et al. defined 


\begin{tabular}{|c|c|c|c|c|c|}
\hline Variable & Outcome type & Time & OR $(95 \% \mathrm{Cl})$ & $P$ & AUC ROC $(95 \% \mathrm{Cl})$ \\
\hline \multirow{4}{*}{ Uric acid concentration } & & 7 days & $\begin{array}{c}1.0087 \\
(1.0015 \text { to } 1.0158)\end{array}$ & 0.017 & $\begin{array}{c}0.6191 \\
(0.4706 \text { to } 0.7676)\end{array}$ \\
\hline & $\begin{array}{l}\text { Adverse maternal } \\
\text { (non-renal) }\end{array}$ & $48 \mathrm{hrs}$ & $\begin{array}{c}1.0039 \\
(0.9943 \text { to } 1.0135)\end{array}$ & 0.429 & $\begin{array}{c}0.5444 \\
(0.3356 \text { to } 0.7532)\end{array}$ \\
\hline & & 7 days & $\begin{array}{c}1.0067 \\
(0.9927 \text { to } 1.0143)\end{array}$ & 0.077 & $\begin{array}{c}0.5973 \\
(0.4464 \text { to } 0.7481)\end{array}$ \\
\hline & & Any time & $\begin{array}{c}1.0056 \\
\text { (0.9991 to } 1.0121)\end{array}$ & 0.093 & $\begin{array}{c}0.5867 \\
(0.4665 \text { to } 0.7070)\end{array}$ \\
\hline \multirow[t]{5}{*}{$\begin{array}{l}\text { Gestational age corrected } \\
Z \text { score of uric acid level }\end{array}$} & Adverse maternal (all) & $48 \mathrm{hrs}$ & $\begin{array}{c}1.5344 \\
(1.0693 \text { to } 2.2017)\end{array}$ & 0.020 & $\begin{array}{c}0.6595 \\
(0.4951 \text { to } 0.8239)\end{array}$ \\
\hline & & 7 days & $\begin{array}{c}1.5540 \\
(1.1579 \text { to } 2.0857)\end{array}$ & 0.003 & $\begin{array}{c}0.6606 \\
(0.5299 \text { to } 0.7913)\end{array}$ \\
\hline & & Any time & $\begin{array}{c}1.5655 \\
(1.2140 \text { to } 2.0187)\end{array}$ & 0.001 & $\begin{array}{c}0.6759 \\
(0.5730 \text { to } 0.7787)\end{array}$ \\
\hline & $\begin{array}{l}\text { Adverse maternal } \\
\text { (non-renal) }\end{array}$ & $48 \mathrm{hrs}$ & $\begin{array}{c}1.5344 \\
(1.0693 \text { to } 2.2017)\end{array}$ & 0.020 & $\begin{array}{c}0.6595 \\
\text { (0.4951 to } 0.8239)\end{array}$ \\
\hline & & 7 days & $\begin{array}{c}1.4574 \\
(1.0760 \text { to } 1.9740)\end{array}$ & 0.015 & $\begin{array}{c}0.6410 \\
(0.5083 \text { to } 0.7738)\end{array}$ \\
\hline
\end{tabular}

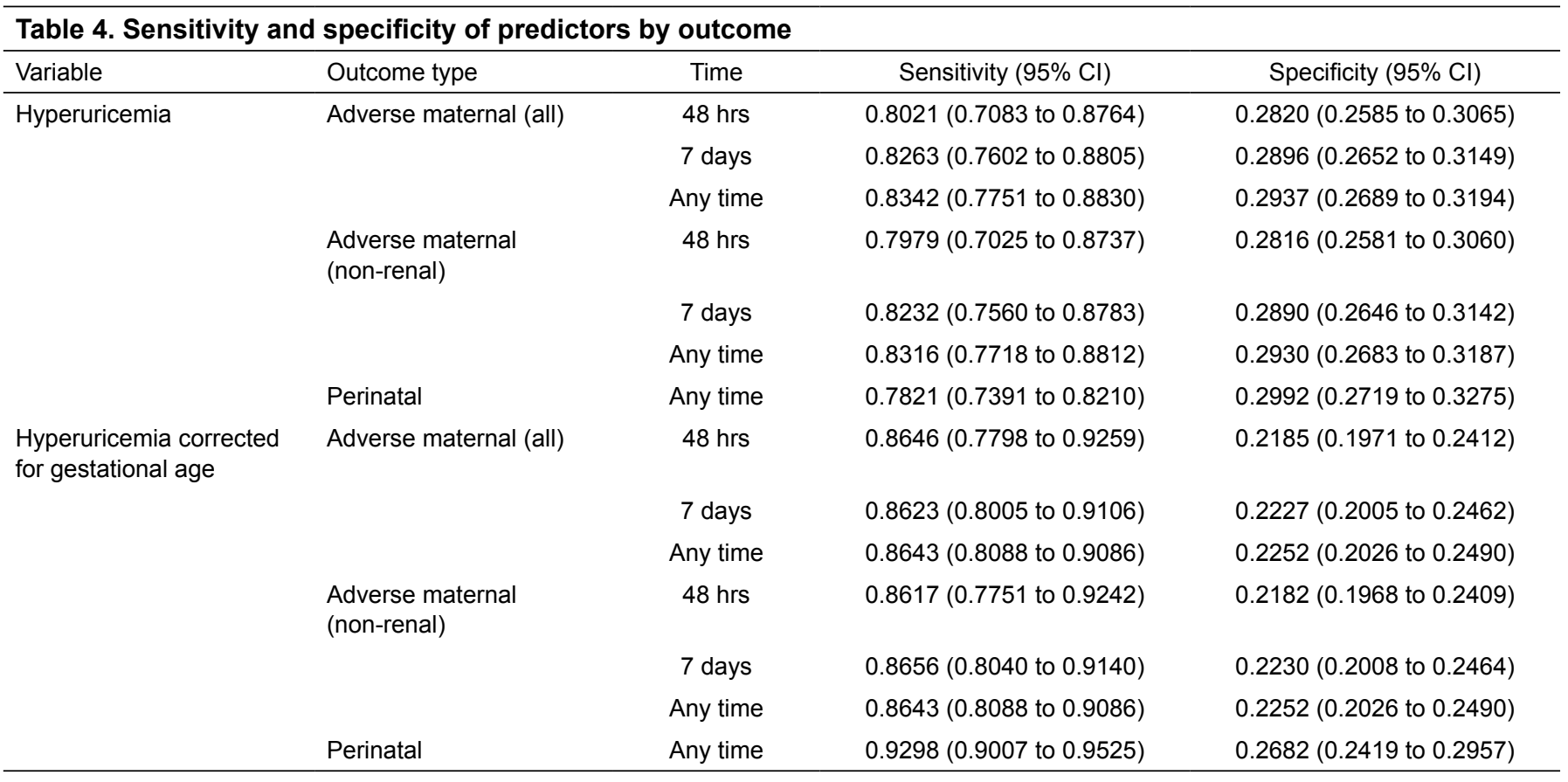


adverse perinatal outcome as one or more of perinatal death (any death after 20 weeks' gestation until maternal discharge from hospital postpartum), small for gestational age infant (SGA; < 10th centile), admission to special-care nursery (criteria for admission included respiratory distress, low birth weight, hypoxia, jaundice and low blood sugar but did not include admission related to genetic disorders) and prematurity $\left(<37+0\right.$ weeks of gestation).$^{13}$ Our choice of outcome (perinatal or infant mortality, admission to NICU for greater than 48 hours, or both) included more serious outcomes.

Despite differences in ORs, both the current study and the study of Hawkins et al. ${ }^{13}$ demonstrate that uric acid $Z$ score performs better than absolute uric acid concentration in predicting adverse perinatal outcomes. The stronger association of uric acid $Z$ score is likely due to the changing values of uric acid concentration during pregnancy; these have been shown to be lowest in the first trimester, to remain relatively stable during the second trimester, and to rise sharply during the final trimester. ${ }^{12}$ This finding was also noted previously by Roberts et al.," who showed that every unit increase in uric acid $Z$ score in women with gestational hypertension and proteinuria increased the odds of preterm birth by 2.3-fold (OR 2.3; 95\% CI 1.7 to 2.9$)$.

In preeclampsia, elevations in serum uric acid beyond the normal gestational concentration are likely influenced by changes in maternal renal function (e.g., increased tubular reabsorption) and uric acid production; however, the fetus and placenta may play additional roles. We found a weak relationship between serum uric acid and serum creatinine, suggesting elevated serum uric acid is likely more than merely a marker of GFR abnormalities. One proposed mechanism by which the placenta may contribute to uric acid production is via hypoxia-induced changes in the production and activity of xanthine oxidase/dehydrogenase. ${ }^{15}$ Increased uric acid concentration may therefore be a better marker of poor placental perfusion and subsequent fetal hypoxia than maternal distress. There is also in vitro evidence for effects of uric acid that might contribute to adverse fetal outcomes. In these studies uric acid reduced placental amino acid transport, ${ }^{16}$ trophoblast invasion, and incorporation of trophoblast into endothelial monolayers. ${ }^{17}$

The odds ratios for uric acid $Z$ score predicting maternal outcomes are in the range of 1.2 to 1.5 , which are again lower than the values reported by Hawkins et al. ${ }^{13}$ (OR 2.1; $95 \%$ CI 1.5 to 2.9 ). As with perinatal outcomes, uric acid $Z$ score performed better than absolute uric acid level in predicting maternal outcomes. None of the mean AUC ROC values met the predetermined threshold of 0.7 , although there was overlap in the $95 \%$ CI for uric acid $Z$ score and adverse maternal outcomes at 48 hours and seven days. Nevertheless, these results indicate that the uric acid level (either absolute or $Z$ score) is less accurate in predicting adverse maternal outcomes than adverse perinatal outcomes in women with preeclampsia. This provides further support for the notion that uric acid concentration may be more associated with fetal and placental changes than maternal changes.

Clinically, a diagnostic screening test using a single cutoff value for serum uric acid to predict outcome would have practical appeal. In this study, the best model for this purpose would be the use of hyperuricemia corrected for gestational age as a predictor of perinatal outcome. However, with a specificity of $27 \%$ and sensitivity of $93 \%$, the positive likelihood ratio is $<2$ and does not meet the utility requirements for a clinical test outlined by Thangaratinam et al. ${ }^{10}$ Thus, while serum uric acid may provide useful information to clinicians, as noted by Koopmans et al., ${ }^{7}$ it does not perform well in isolation as a diagnostic screen. Adding hyperuricemia corrected for gestational age to a multivariable model is likely a better approach to improving predictive performance.

This study is limited by the fact that only the highest uric acid level was recorded; therefore, neither the length of time that uric acid levels were raised nor the magnitude of intraindividual change was accounted for. While a temporal effect of elevated serum uric acid may influence both maternal and perinatal events, clinical management decisions are often made based on single laboratory values, and thus this may better reflect utility in practice. It could be argued that another limitation of this study is the use of a combined measure for perinatal outcome (predominantly NICU admission for more than 48 hours). This somewhat limits comparison with other studies (e.g., those that categorized SGA as adverse outcomes), but it is likely to better reflect true adverse clinical outcomes. It is unlikely that missing data significantly influenced our analyses because only 18 of 1505 women $(1.2 \%)$ were eliminated for this reason; only five of these 18 women suffered an adverse maternal outcome and one had an adverse perinatal outcome. The final limitation of the study is the exclusion of women with hypertensive disorders other than preeclampsia (i.e., preexisting and gestational hypertension $\left.{ }^{18,19}\right)$. As preeclampsia and hyperuricemia are closely linked, it may be that uric acid $Z$ scores, for example, have greater utility across the breadth of pregnancy hypertension than in a population limited to women with preeclampsia.

Identifying women with preeclampsia who are at increased risk for adverse perinatal outcomes would have a significant 
impact on maternal management. This knowledge would also help inform clinicians regarding patient transfer to a centre with NICU facilities. Given the current results, uric acid $Z$ score is a good model for predicting adverse perinatal outcomes, but a threshold value for uric acid corrected for gestation performed less well. To address this, it may be worthwhile to incorporate uric acid $Z$ score into a multivariable prediction model to strengthen the utility.

\section{CONCLUSION}

The association between elevated serum uric acid concentration and preeclampsia has been studied for decades, with inconsistent results from studies assessing the usefulness of maternal serum uric acid in predicting adverse outcomes. In this study, serum uric acid corrected for gestational age via a $Z$ score was shown to be useful in predicting adverse perinatal outcomes in women admitted to hospital with preeclampsia. Maternal uric acid concentration, including $Z$ score, was also evaluated for predicting adverse maternal outcomes in the same cohort but the results did not show significant predictive value.

\section{ACKNOWLEDGEMENTS}

Funding for this study was provided by the following: Canadian Institutes for Health Research; UNDP/ UNFPA/WHO/World Bank Special Programme of Research, Development \& Research Training in Human Reproduction; Preeclampsia Foundation; International Federation of Obstetricians and Gynaecologists; Michael Smith Foundation for Health Research; Child and Family Research Institute.

The authors would like to thank the members of the PIERS working group (http://pre-empt.cfri.ca/monitoring/ fullpiers) for their contributions to this work.

\section{REFERENCES}

1. Steegers EAP, von Dadelszen P, Duvekot JJ, Pijnenborg R. Pre-eclampsia. Lancet 2010;376:631-44.

2. von Dadelszen P, Payne B, Li J, Ansermino JM, Pipkin FB, Côté AM, et al. Prediction of adverse maternal outcomes in pre-eclampsia: development and validation of the fullPIERS model. Lancet 2011;377:219-27.
3. Payne BA, Hutcheon JA, Ansermino JM, Hall DR, Bhutta ZA, Bhutta SZ, et al. A risk prediction model for the assessment and triage of women with hypertensive disorders of pregnancy in low-resourced settings: the miniPIERS (Pre-eclampsia Integrated Estimate of RiSk) Multi-country Prospective Cohort Study. PLoS Med 2014;11(1):e1001589.

4. Kang DH, Finch J, Nakagawa T, Karumanchi SA, Kanellsi J, Granger J, et al. Uric acid, endothelial dysfunction and pre-eclampsia: searching for a pathogenetic link. J Hypertens 2004; 22:229-35.

5. Bainbridge SA, Roberts JM. Uric acid as a pathogenic factor in preeclampsia. Placenta 2008;29(Suppl A):S67-72.

6. Martin AC, Brown MA. Could uric acid have a pathogenic role in pre-eclampsia? Nat Rev Nephrol 2010; 6:744-8.

7. Koopmans CM, van Pampus MG, Groen H, Aarnoudse JG, van den Berg PP, Mol BW. Accuracy of serum uric acid as a predictive test for maternal complications in preeclampsia: bivariate meta-analysis and decision analysis. Eur J Obstet Gynecol Reprod Biol 2009;146:8-14.

8. Bellomo G, Venanzi S, Saronio P, Verdura C, Narducci PL. Prognostic significance of serum uric acid in women with gestational hypertension. Hypertension 2011;58:704-8.

9. Roberts JM, Bodnar LM, Lain KY, Hubel CA, Markovic N, Ness RB, et al. Uric acid is as important as proteinuria in identifying fetal risk in women with gestational hypertension. Hypertension 2005;46(6):1263-9.

10. Thangaratinam S, Ismail KM, Sharp S, Coomarasamy A, Khan KS. Accuracy of serum uric acid in predicting complications of preeclampsia: a systematic review. BJOG 2006;113:369-78.

11. Williams KP, Galerneau F. The role of serum uric acid as a prognostic indicator of the severity of maternal and fetal complications in hypertensive pregnancies. J Obstet Gynaecol Can 2002;24:628-32.

12. Lind T, Godfrey KA, Otun $\mathrm{H}$. Changes in serum uric acid concentrations during normal pregnancy. Br J Obstet Gynaecol 1984;91:128-32.

13. Hawkins T, Roberts J, Mangos G, Davis G, Roberts L, Brown M. Plasma uric acid remains a marker of poor outcome in hypertensive pregnancy: a retrospective cohort study. BJOG 2012;119:484-92.

14. Royston P, Altman DG. Visualizing and assessing discrimination in the logistic regression model. Stat Med 2010;29:2508-20.

15. Many A, Hubel CA, Fisher SJ, Roberts JM, Zhou Y. Invasive cytotrophoblasts manifest evidence of oxidative stress in preeclampsia. Am J Pathol 2000;156:321-31.

16. Bainbridge SA, Von Versen-Hoynck F, Roberts JM. Uric acid inhibits placental system A amino acid uptake. Placenta 2009;30:195-200.

17. Bainbridge SA, Roberts JM, Von Versen-Hoynck F, Koch J, Edmunds L, Hubel CA. Uric acid attenuates trophoblast invasion and integration into endothelial cell monolayers. Am J Physiol Cell Physiol 2009; 297:C440-50.

18. Payne B, Magee LA, von Dadelszen P. Assessment, surveillance and prognosis in pre-eclampsia. Best Pract Res Clin Obstet Gynaecol 2011;4:449-62.

19. Magee LA, Pels A, Helewa M, Rey E, von Dadelszen P; on behalf of the Canadian Hypertensive Disorders of Pregnancy Working Group. Diagnosis, evaluation, and management of the hypertensive disorders of pregnancy. Pregnancy Hypertens 2014;4 (2):105-45. 